\title{
PARADIGMA ILMIAH \\ PADA ILMU SOSIAL-BUDAYA KONTEMPORER
}

\author{
Akhyar Yusuf
}

\begin{abstract}
An American philosopher, Thomas Samuel Kuhn (1922-1996) in his books, The Structure of Scientific Revolution (1962) and The Essential Tension; Selected Studies in Scientific Tradition and Change (1977) poses a paradigm of a universal foundation of science which uses a common fact, method, language and criteria. He does not think that even in the realm of the natural sciences, there are differences, more so that there is a paradigm in the humanities including the arts and literature. Kuhn, however, has established a new paradigm for the philosophy of science which he called "the sociology of science" or a social construction, which now is popular as a constructive paradigm. It is developed in the Critical Theory of Adorno, Horkheimer, and Habermas, and in the Postmodern Theory of Lyotard, Derrida, Foucault, and Baudrillard. The paradigm of the social-political and cultural discourses of the seventies, has developed from structuralism of Saussure and Levi Strauss to post-structuralism or deconstructionism of Jacques Derrida and Paul de Mann referring to contemporary or postmodern era. It rejects stable understanding, logocentrism, antibinary, and gives readers ways to understand a text. The methods used is interpretative paradigm, such as philology, Marxist, new historicism, structuralism, psychoanalysis, theory of acceptance, semiotics, deconstruction, and discourse analysis.
\end{abstract}

\section{Keywords}

Paradigm, social construction, contemporary, post-modern era.

\section{PENGANTAR}

Pada bulan Desember 2010 Fakultas Ilmu Pengetahuan Budaya meluncurkan jurnal baru yang berjudul Paradigma. Judul jurnal ini melahirkan harapan kalau saja jurnal ini dapat berfungsi sebagai dialog ilmuwan yang berkaitan dengan berbagai masalah paradigma ilmiah, asumsi-asumsi dalam ilmu, teori-teori dan kerangka konseptual yang bersaing dalam dunia akademis, pembahasan tentang berbagai metode yang digunakan dalam dunia ilmiah, paling tidak pada ilmu sosial-budaya. Ada banyak perubahan sekitar pandangan dunia ilmiah akhir-akhir ini yang perlu dikomunikasikan dan dipahami kalangan akademisi, sehingga kita dapat mengikuti perkembangan dan memberikan materi kuliah yang dapat membantu mahasiswa untuk memahami dan menjelaskan problem kekinian. 
Dalam dunia akademis istilah paradigm atau paradigma dipopulerkan oleh Thomas Samuel Kuhn (1922-1996), filsuf Amerika yang pemikirannya berpengaruh luar biasa bagi perkembangan ilmu pengetahuan kontemporer. Gagasan paradigma itu ia kemukakan melalui buku tipis yang berjudul The Structure of Scientific Revolutions, (1962). Cetakan kedua buku ini diterbitkan pada tahun 1970 dengan menambahkan post-script yang sangat penting. Buku keduanya adalah The Essential Tension; Selected Studies in Scientific Tradition and Change (Chicago and London: University of Chicago Press, 1977).

Kuhn adalah doktor dan profesor fisika yang pemikiran awalnya sangat dipengaruhi oleh paradigma positivisme Lingkaran Wina yang menekankan kesatuan ilmiah (unified science), di mana semua ilmu pengetahuan dituntut untuk menggunakan fondasi yang sama. Artinya ilmu pengetahuan hanya diakui ilmiah, jika dan hanya berdasarkan pada fakta, metode, bahasa, dan kriteria yang sama. Tidak diakui ada metode, kriteria, dan bahasa yang berbeda antara ilmu pengetahuan alam, sosial-budaya termasuk seni dan sastra. Penelitian genealogis Kuhn justru membuktikan bahwa dalam ilmu pengetahuan alam sendiri senantiasa terjadi loncatan atau peralihan paradigma pada era tertentu. Ada perbedaan pandangan dunia ilmiah (paradigm sift) antara Aristoteles, Newton, dan Einstein dalam melihat dan meneliti dan menjelaskan alam. Penelitian Kuhn, yang awalnya hanya untuk materi kuliah fisika (mekanika klasik) yang dipercayakan kepadanya, ternyata berdampak besar pada dua hal. Pertama, ia menghasilkan bidang filsafat ilmu pengetahuan baru yang disebut dengan "sosiologi pengetahuan" atau "sosial konstruksi" dan kedua, yang sekarang berkembang menjadi paradigma konstruktivisme yang mendapat dukungan dari critical theory (Adorno, Horkheimer, Habermas) dan postmodern theory (Lyotard, Derrida, Foucault, Baudrillard).

Perbedaan pandangan dunia atau pandangan ilmuwan tentang realitas yang diteliti (asumsi ontologis) memiliki keterkaitan dengan penggunaan epistemologis (filsafat ilmu dan metodologi) dan nilai-nilai (axiology) yang ada pada setiap paradigma. Terdapat pandangan tentang realitas fisika, tentang konsep ruang dan waktu yang berbeda antara Aristoteles dengan Kepler dan Newton, serta antara Newton dan Einstein (fisika kuantum). Perbedaan pandangan mereka tentang fenomena alam berdampak pada penggunaan metodologi dan keterkaitan ilmu dengan nilai-nilai serta kebenaran ilmiah. Ada pandangan dunia ilmiah yang berbeda antara Aristoteles dengan Newton dan Einstein sehingga mereka melihat dan menghasilkan teori yang berbeda.

Paradigma Aristotelean menganggap alam sebagai pusat alam semesta (geosentris), alam memiliki tujuan tertentu, misalnya untuk kembali ke asalnya (buah apel jatuh karena rindu atau ingin kembali ke asalnya, yaitu tanah). Paradigma Newtonian mengubah pandangan dunia (asumsi metafisik) Aristotelean itu dengan alam yang mekanis dan matematis. Asumsi-asumsi metafisik dalam fisika Newtonian antara lain, alam tidak memiliki tujuan seperti yang dikemukakan Aristoteles bahwa apel jatuh karena mengikuti hukum alam (gravitasi). Alam dalam fisika Newton bergerak seperti 
mesin (mekanis dan matematis); alam itu ibarat sebuah buku besar, dan dapat dibaca atau dipahami jika kita mengetahui bahasanya. Bahasanya adalah bahasa matematika sehingga muncul tuntutan penggunaan penelitian eksperimental-kuantitatif pada ilmu pengetahuan modern yang didasarkan atas paradigma Newtonian. Einstein dan ahli fisika kuantum melakukan perubahan paradigma ilmiah Newtonian secara drastis. Pergantian paradigma itulah yang sesungguhnya menimbulkan perkembangan dalam dunia ilmu pengetahuan yang disebut Kuhn sebagai revolusi ilmu pengetahuan (Lubis, 2010).

\title{
PENGERTIAN PARADIGMA
}

Lalu apa yang dimaksud dengan paradigma oleh Kuhn? Kuhn mengemukakan konsep paradigma sebagai berikut.

\begin{abstract}
"A paradigm is a fundamental image of the subject matter within a science. It serves to define what should be studied, what question should be asked, how they should be asked and what rules should be followed in interpreting the answer obtained. The paradigm is the broadest unit of consensus within a science and serves to differentiate one scientific community (or subcommunity) from another. It subsumes, defines, and interrelates the exemplars, theories, methods and instrument, that exist within it" (Ritzer 1996, 500).
\end{abstract}

Secara umum Kuhn mengartikan paradigma dengan beberapa contoh praktik ilmiah aktual yang diterima, seperti hukum, teori, aplikasi, dan instrumen yang diterima bersama sehingga merupakan model yang dijadikan sebagai sumber dan tradisi yang mantap dalam riset-riset ilmiah khusus (Kuhn 1970, 10). Paradigma dapat berarti 'pola', 'model' atau 'skema konseptual' dalam memahami aspek-aspek tertentu tentang realitas (ontologi). Istilah paradigma merupakan konsep yang sangat sentral pada filsafat ilmu pengetahuan Kuhn. Sayangnya, Kuhn tidak memberikan pengertian yang tegas dan jelas tentang istilah itu. Kuhn menggunakan pengertian paradigma dengan dua puluh satu pengertian yang berbeda-beda. Kemudian, Masterman membantu untuk menjelaskan pengertian paradigma Kuhn dengan mereduksi dua puluh satu konsep Kuhn pada tiga tipe paradigma. Tipe paradigma itu antara lain 1) paradigma metafisik atau metaphysical paradigm, 2) paradigma sosiologis, sociological paradigm, dan 3) paradigma konstruk, construct paradigm (Ritzer, 2002: 4). Paradigma metafisik berkaitan dengan asumsi-asumsi ontologis yang terkandung secara inheren dalam setiap paradigma. Misalnya, paradigma positivisme mengandung asumsi ilmu hanya berbicara tentang obyek (realitas) yang dapat diamati. Realitas atau obyek itu ditentukan oleh hukum alam yang universal serta dapat dikuantifikasi dan diverifikasi. Karena itu, metode yang digunakan adalah metode empiris eksperimental. Sedangkan paradigma sosiologis berkaitan dengan exemplar atau model penelitian yang digunakan pada tiap-tiap paradigma. Misalnya, exemplar penelitian psikologi positivis antara lain penelitian Pavlov dan penelitian Skinner. Exemplar penelitian pada paradigma psikoanalisis adalah penelitian Freud, Jung, Adler; 
exemplar penelitian paradigma humanistik adalah penelitian Abraham Maslow dan Viktor Frankl. Sedangkan paradigma psikologi kritis dan posmodern menggunakan model penelitian psikologi feminis dan psikologi multikultural dengan tokoh-tokohnya Steiner Kvale, Erica Burman, Tod Sloan.

Pada kajian sosial-politik dan budaya, paradigma yang digunakan secara umum memiliki persamaan dengan paradigma psikologi. Berbeda dengan kajian yang tidak mungkin menggunakan paradigma positivisme, dan secara umum boleh dikatakan hanya menggunakan metodehermeneutika denganberbagai varianmetodenya. Meskipundalam beberapa hal dipengaruhi oleh gagasan positivisme ilmiah, strukturalisme tetap berbeda dengan positivisme karena struktur atau sistem yang dianggap sebagai dasar fenomena bukan sesuatu yang dapat diobservasi. Struktur atau sistem pada Ferdinand de Saussure, Levi Strauss, dan psikologi Freud adalah sesuatu yang metafisis. Ketidakmungkinan menggunakan metode empiris-eksperimental pada karya sastra (puisi, novel) karena karya itu merupakan pengalaman eksistensial, karya sebagai perpaduan antara pengalaman, imajinasi, rasionalitas, hasrat manusia. Karena itu, metode yang digunakan pada kajian sastra (filologi, kritik marxis, historisisme baru, strukturalisme, psikoanalisis, teori penerimaan, semiotika, dekonstruksi, analisis wacana) adalah metode yang masuk pada payung paradigma interpretatif (hermeneutika-fenomenologi).

\section{PERGESERAN PARADIGMA}

Satu contoh pergeseran atau pergantian paradigma ilmiah dalam kajian satra dan budaya adalah pergantian dari strukturalisme ke postrukturalisme (dekonstruksionis) Jacques Derrida dan Paul de Mann. Peralihan dari strukturalisme ke dekonstruksionisme mengandung konsekuensi ontologis, epistemologis, dan aksiologis yang mendasar. Pergeseran paradigma ilmiah berdampak pada beberapa unsur/pengertian:

1. Munculnya cara berpikir baru mengenai masalah baru. Jika seseorang melakukan penelitian dengan menggunakan metode dekonstruksi, maka sebagai asumsi fenomena sosial-budaya, bahasa ditentukan oleh struktur atau sistem yang stabil, logika oposisi biner (misalnya antara langue vs parole, antara signifiant vs signifie', antara diakroni dan sinkroni, antara sintakmatik vs paradigmatik) harus ditinggalkan. Dekonstruksionis menolak adanya makna yang stabil, logosentrisme, dan model berpikir oposisi biner, namun menerima kebebasan pembaca atau penafsir untuk memaknai teks, mementingkan intertektualitas, serta penafsiran yang tidak berakhir.

2. Hadirnya asumsi-asumsi baru yang imanen pada paradigma namun tidak kita kenal atau tidak disadari pengguna paradigma itulah yang disebut dengan dimensi yang tak terungkap menurut Michel Polanyi.

3. Paradigma baru tidak dapat diterapkan kecuali dengan meningggalkan paradigma 
lama (prinsip incommonsurable). Ketika seorang strukturalis mengubah paradigma berpikirnya, misalnya dari positivisme ke interpretatif dan fenomenologi, atau dari strukturalisme ke postrukturalisme, ia harus meninggalkan paradigma lama supaya ia dapat bekerja secara benar dan konsisten dengan paradigma baru itu. Konsep incommonsurable ini yang diistilahkan oleh posmodernis dengan languagames atau aturan permainan bahasa yang dikemukakan Wittgenstein dan diterima posmodernis umumnya. Maksudnya aturan permainan bahasa yang beragam identik dengan aturan permainan bola yang beragam (bola kaki, voli, kasti) di mana setiap permainan hanya bisa berjalan jika masing-masing bertindak sesuai dengan aturan permainan yang ditetapkan. Aturan pada setiap paradigma pada setiap metode berbeda, misalnya strukturalisme, psikoanalisis, dekonstruksi. Karena itu, aturan dan kriteria pada strukturalisme tidak kompatibel dengan dekonstruktivisme.

4. Paradigma baru selalu ditanggapi dengan kecurigaan dan permusuhan (ingat tantangan terhadap Giordano Bruno dan Galileo Galilei sewaktu mereka mengajukan teori heliosentris yang menggeser teori geosentris yang didukung oleh tokoh-tokoh gereja) (Smith, Linda \& W. Raeper 2000, 247). Ilmuwan yang sudah terbiasa dan hanya memahami paradigma positivisme, atau strukturalisme, akan sulit untuk menghargai dan menerima paradigma kritis dan posmodernisme. Kehadiran model berpikir baru biasanya dihadapi dengan penuh kecurigaan. Sedangkan untuk mengubah paradigma atau cara berpikir itu sangat sulit karena perlu upaya dan kerja keras untuk memahami hal-hal yang baru itu. Kuhn sendiri mengibaratkan kesulitan untuk perubahan paradigma ilmiah itu seperti mengubah agama atau keyakinan.

\section{BERPIKIR BARU DAN FENOMENA BARU}

Dalam pemikiran teoretisi sosial-budaya posmodern, teori sosial-budaya modern sebagaimana dikemukakan oleh pemikir modern dianggap tidak memadai untuk memahami masalah sosial-budaya kontemporer. Dalam ilmu sosial-politik pemikiran Auguste Comte, Herbert Spencer, Emille Durkheim (paradigma positivisme); pemikiran Karl Marx, Robert Park, Vilfredo Pareto, Thorstein Veblen (paradigma konflik); pemikiran Max Weber, George Mead, George Simmel (paradigma perilaku sosial); pemikiran Talcott Parson, Walter Buckley, Emitai Edzioni, Edward Tiryakian (paradigma struktur fungsional) dianggap tidak tepat dan tidak mampu lagi digunakan untuk memahami dan menjelaskan masalah sosial-politik setelah tahun 1970-an (era kontemporer atau posmodern).

Para pemikir modern tersebut berupaya keras berpikir dan menghadapi masalah awal munculnya modernisme, kapitalisme awal, masalah pertentangan buruh dengan pemilik modal, masalah rasionalisasi, tetapi tidak pernah membayangkan munculnya 
masalah posindustri, globalisasi, konsumerisme, gender dan tuntutan keadilan kaum perempuan, multikulturalisme, simulacra, hyperreality, cyberpolitics, cyberculture, ancaman pemanasan global, dan lain-lain. Pemikir neo-Marxis, seperti Antoni Gramcy dan Louis Althusser, dan critical theory seperti Adorno, Horkheimer, dan Hebermas telah menyadari kekurangan teori Modern (khususnya Marxis) untuk menjelaskan fenomena sosial-budaya baru. Karena itu, mereka mengembangkan pemikiran Marxis itu sehingga muncul teori baru yang disebut dengan neo-Marxis. Kemudian pemikir postrukturalis dan posmodern, seperti Francois Lyotard, Jacques Derrida, Roland Barthes, Michel Foucault, Richard Rorty, Fredric Jameson, dan Jean Baudrillard, memberi sumbangan pemikiran (metode) baru untuk membantu kita memahami masalah sosial-budaya kontemporer.

Postrukturalis dan posmodern sesungguhnya juga bisa disebut sebagai teori kritis. Gagasan teori kritis dan posmodernis memiliki lebih banyak kemiripan daripada perbedaan, walaupun harus disadari bahwa kritik postrukturalis atau posmodernis terhadap ilmu pengetahuan dan kebudayaan modern bergerak lebih radikal dari critical theory. Pemikiran postrukturalis dapat dikatakan pintu masuk ke posmodern, dan pemikir postrukturalis juga adalah posmodernis, namun tidak semua posmodernis dapat disebut sebagai postrukturalis. Dalam kajian sosial-budaya sekarang ini teori kritis, postrukturalisme dan posmodernisme merupakan kerangka konseptual dan teori yang harus dipahami karena kajian sosial-budaya kontemporer berkembang di atas dasar pemikiran ini.

Kalau dikatakan postrukturalisme sebagai pintu masuk ke posmodernisme, akan lebih mudah dan tepat jika kita mencoba memasuki gagasan posmodernisme dengan mengawalinya dengan mengontraskan strukturalisme dengan postrukturalisme, sebagai berikut.

\begin{tabular}{|l|l|l|}
\hline No & \multicolumn{1}{|c|}{ Strukturalisme } & \multicolumn{1}{c|}{ Postrukturalisme } \\
\hline 1 & $\begin{array}{l}\text { Ada struktur bahasa/budaya yang } \\
\text { stabil dan oposisi biner }\end{array}$ & Menolak struktur yang stabil dan oposisi biner \\
\hline 2 & $\begin{array}{l}\text { Menekankan makna yang obyektif, } \\
\text { stabil, universal yang ditentukan oleh } \\
\text { struktur }\end{array}$ & $\begin{array}{l}\text { Menolak makna yang obyektif-universal dan } \\
\text { stabil. Makna selalu tertunda, trace, makna } \\
\text { terkait dengan konteks dan interteks }\end{array}$ \\
\hline 3 & Menerima linearitas sejarah & $\begin{array}{l}\text { Menolak linearitas, historisisme, memperhati- } \\
\text { kan event, dan konteks }\end{array}$ \\
\hline 4 & Sinkronis (ahistoris) & Diakronis (menekankan sejarah, historis) \\
\hline 5 & Menekankan pada langue & $\begin{array}{l}\text { Mengutamakan parole, karakter relasional } \\
\text { makna bahasa dan produksi makna melalui } \\
\text { perbedaan }\end{array}$ \\
\hline 6 & $\begin{array}{l}\text { Pemirsa atau pembaca pasif, } \\
\text { menekankan pada tanda dan makna } \\
\text { yang sesuai dengan struktur }\end{array}$ & $\begin{array}{l}\text { Pemirsa dan pembaca aktif (pengarang mati), } \\
\text { menekankan pencarian makna seluas-luasnya, } \\
\text { multivokalitas }\end{array}$ \\
\hline
\end{tabular}




\begin{tabular}{|l|l|l|}
\hline 7 & $\begin{array}{l}\text { Subyek tidak bebas, subyek mati } \\
\text { (ditentukan oleh struktur/sistem yang } \\
\text { metafisik }\end{array}$ & $\begin{array}{l}\text { Subyek bukan entitas universal, subyek memi- } \\
\text { liki kebebasan terbatas, subyek dikonstruksi } \\
\text { oleh budaya (bahasa, wacana, politik, ekonomi, } \\
\text { dan lain-lain). }\end{array}$ \\
\hline
\end{tabular}

Tabel di atas baru menjelaskan sebagian perbedaan antara strukturalisme (memiliki banyak persamaan dengan modern) dan postrukturalisme (banyak persamaan dengan posmodern). Adalah sulit untuk meringkas pemikiran tokoh teori kritis, postrukturalis, dan posmodernis yang memengaruhi kajian sosial-politik dan budaya kontemporer yang sangat luas dan beragam itu. Pada tulisan ini kita memetik hal penting dari pemikiran Teori Kritis (Neo-Marxis), antara lain ideologi dan hegemoni dari Gramci, keterkaitan antara ilmu pengetahuan dengan kepentingan dan nilai dari Habermas. Pemikiran Habermas tentang keterkaitan antara teori dengan praxis menggunakan teori feminis, poskolonial, atau teologi pembebasan untuk membebaskan individu dan kelompok dari dominasi dan ketidakadilan (dimensi emansipatoris). Dalam pemikiran Teori Kritis, ilmu harus dapat digunakan untuk membongkar ideologi dan ilusi yang disodorkan kepada ilmuwan atas nama obyektivitas dan bebas nilai.

Jika Teori Kritis dibandingkan dengan Pemikiran Posmodernis, pemikiran posmodernis bergerak ke arah yang lebih luas dan radikal. Meskipun demikian, Teori Kritis dan Posmodern secara bersama-sama dianggap sebagai titik-tolak dalam mengembangkan teori sosial-politik dan budaya kontemporer. Ada banyak pemikir posmodernis yang mengubah cara berpikir yang cukup radikal dari berbagai bidang ilmu (khususnya sosial-budaya), sehingga tidak mungkin pemikiran yang luas dan beragam itu dapat dikemukakan di dalam tulisan ringkas ini. Namun, ada konsep kunci yang umumnya digunakan posmodernis pada berbagai bidang ilmiah, seperti dekonstruksi, perbedaan, intertektualitas, mininarasi, pembedaan diskursus-figur, language games, antifundasionalisme, antiesensialisme, dan konstruksitivisme.

Untuk lebih memperjelas perbedaan model berpikir modern dengan posmodern, ada baiknya dikemukakan pemikiran Zygmunt Bauman dalam buku, Legislators and Interpreters: On Modernity, Postmoderniy and Intelectuals (1987), yang membedakan tipe intelektual modern yang ia sebut dengan "tipe legislator" dengan tipe berpikir posmodern yang ia sebut "tipe interpreter" sebagai berikut.

\section{Tipe pertama}

Tipe Legislator:

1. memiliki kewenangan mengatasi perbedaan;

2. pendapat legislator benar dan mengikat;

3. memiliki otoritas karena ilmu yang lebih unggul dari yang lain;

4. ilmuwan memiliki akses yang lebih baik pada ilmu daripada awam;

5. ilmuwan pemilik kolektif atas pengetahuan yang dihasilkan; 
6. ilmu dianggap berhubungan langsung dengan perbaikan sosial;

7. ilmuwan tidak terikat dengan tradisi lokal dalam menjustifikasinya;

8. ilmuwan melakukan kontrol terhadap aturan dan aplikasi ilmu.

Tipe legislator adalah metafor untuk menggambarkan ilmuwan yang memiliki kewenangan untuk menentukan mana teori yang benar dan mana yang salah sebagaimana tugas seorang hakim pada dunia pengadilan. Paradigma positivisme adalah model berpikir oposisi biner yang menentukan bahwa yang benar adalah paradigma positivisme dan di luar itu salah, berbeda dengan model berpikir seorang interpretator (posmodern) yang bebas memberikan penafsiran sesuai dengan standpoint dan paradigma yang digunakannya. Metode interpretasi dan fenomenologi adalah metode yang diandalkan oleh posmodernis yang memberikan kewenangan bagi pembaca atau penafsir untuk menyingkap makna seluas-luasnya yang terkandung pada teks. Dalam pemikiran hermeneutika kritis dan posmodernis (dekonstruksionis), penulis "sudah mati" dan sebagai gantinya penafsir atau pembaca memiliki keleluasaan menemukan makna teks seluas-luasnya dengan syarat argumen harus jelas dan kuat.

Tipe kedua adalah berpikir sebagai interpreter, yang dapat dirumuskan sebagai berikut.

1. Interpreter menafsirkan ide-ide dalam komunitas (perspektif, paradigma) tertentu. 2. Interpreter tidak berorientasi mencari ide terbaik, tujuannya untuk memfasilitasi komunikasi bebas antarkomunitas.

3. Interpreter berusaha mencegah distorsi dalam komunikasi.

4. Interpreter perlu pemahaman yang dalam dan luas.

5. Interpreter perlu menjaga keseimbangan antar tradisi dan wacana yang berlawanan.

Suara dan wacana yang beragam itu dibiarkan berkembang sejauh ia bergerak dalam tataran wacana dan dialog, tanpa kekerasan. Menurut Rorty, kekerasan dalam bentuk tindakan apa dan bagaimanapun tidak dibenarkan, sehingga harus dihindari. Sejalan dengan tipe interpreter Bauman, Richard Rorty mengemukakan bahwa dalam dunia ilmiah yang plural dengan keberagaman wacana, tugas seorang ilmuwan bukanlah menentukan "ini benar" dan "itu salah" seperti seorang hakim (positivisme ilmiah). Sikap seorang ilmuwan dalam era pluralisme wacana dan budaya adalah bertindak sebagai seorang moderator atau polisi lalu lintas yang bisa mengatur lalu lintas pemikiran yang begitu melimpah dan beragam dalam arena percakapan global sekarang ini (Rorty 1982, Lubis 2004).

\section{KAJIAN BUDAYA KONTEMPORER}

Pemikiran Kuhn, Heidegger, dan Hermeneutika Kritis (Habermas, Paul Ricoeur, 
Gadamer) dianggap membuka ruang bagi pluralitas paradigma, pluralitas penafsiran. Hasilnya adalah munculnya keberagaman suara atau multivokalitas wacana dalam dunia ilmiah. Teori kritis dan posmodernis juga mengkritik pendekatan ilmiah yang menekankan obyektivitas, universalitas, dan pengetahuan yang terkotak-kotak (spesialisasi yang ketat), di samping menekankan perlunya pendekatan transdisipliner dan multidisipliner. Selain itu, perkembangan ilmu pengetahuan dan teknologi komputer dan internet semakin membuka ruang bagi cara berpikir baru (keterjalinan) serta pendekatan lintas-disipliner dan multidispliner. Dasar berpikirnya adalah fenomena sosial-budaya adalah fenomena yang berkaitan, sehingga masalah sosial, ekonomi, politik, psikologi, dan filsafat tidak dapat dipisahkan secara ketat satu dengan yang lainnya.

Pendekatan transdisipliner dan multidisipliner itu akan terasa sekali jika kita membaca tulisan pemikir teori kritis dan posmodernis. Membaca pikiran Habermas, Derrida, Foucault, dan Rorty, kita dibawa secara bersama pada masalah sosial, politik, hukum, etika, hak-asasi, filsafat, bahkan terorisme. Masalah yang berbeda dan berkaitan dapat dibahas dalam satu buku atau dalam buku yang berbeda. Yang jelas pemikiran mereka luas dan tidak hanya memahami satu bidang ilmiah saja. Agak terasa aneh jika dunia akademis hanya menghargai tulisan seorang ilmuwan (dosen) jika sesuai dengan apa yang disebut sebagai spesialisasinya, dan dianggap tidak bernilai tulisan di luar itu. Keterkurungan ilmuwan dalam kotak spesialisnya tidak sesuai dengan semangat zaman yang disebut oleh Gillez Deleuze dan Felix Guattari dengan era keterjalinan "rhizomatic" ini.

Gilles Deleuze dan Felix Guattari dalam buku, A Thousand Plateaus (1987) mengemukakan model berpikir yang secara metafor disebut "Arbolic" atau arboresen (pohon) dan "rhizomatic" (tumbuhan menjalar, umbi-umbian) yang dapat kita identikan dengan model berpikir modern versus posmodern. Perbedaan paradigma berpikir itu sebagai berikut.

\begin{tabular}{|l|l|l|}
\hline & Arbolic & Rhizomatic \\
\hline 1 & Linear & Non-linear \\
\hline 2 & Hiererchic & Anarchic \\
\hline 3 & Sedentary & Nomadic \\
\hline 4 & Striated & Smooth \\
\hline 5 & Territorialized & Deterritorialized \\
\hline 6 & Unitary \& Binary & Multiplicitous \\
\hline 7 & Major science & Minor Science \\
\hline
\end{tabular}

Arbolic adalah model berpikir modern yang melihat dunia ilmu pengetahuan sebagai sebatang pohon (pohon ilmu). Ilmu pengetahuan dilihat sebagai pohon yang 
berdiri di atas topangan akar tunjang tempat akar-akar lain bertumbuh. Akar tunjang (metafisika, ontologi) adalah yang menunjang berdirinya batang (metode) yang pada batang itu tumbuh cabang besar (ilmu pengetahuan alam), cabang ilmu pengetahuan sosial, dan cabang ilmu pengetahuan budaya. Dari cabang itu tumbuh ranting-ranting (ilmu pengetahuan baru). Model berpikir "arbolic" ini menurut Deeluze dan Guattari serta pemikir Kritis dianggap tidak lagi memadai.

Teori kritis dan posmodern melihat ilmu pengetahuan dengan menggunakan model berpikir baru, melihat ilmu pengetahuan dan cara berpikir "rhizomatic". Rhizome adalah tumbuhan menjalar atau umbi-umbian yang batangnya menjalar ke mana-mana, di mana batang-batang kecil menjalar ke segala arah, berkaitan dan tumpang tindih dengan akar yang memiliki fungsi yang sama (nonlinear), tidak hierarkis tetapi anarkis, bergerak dan dinamis (nomadis), licin dan cair (kontekstual, lokal), tanpa teritori yang jelas (keterjalinan, transdisipliner), multiplisitas dan multivokal, sehingga ilmu atau teori tidak dalam bentuk grand-narrative, tetapi dalam bentuk narasi-narasi kecil (petite` recite).

Kajian budaya kontemporer, seperti kajian feminis, tubuh perempuan, media, seks, ras, etnisitas, budaya iklan, poskolonial, multikultural, adalah kajian yang tidak dapat dipahami tanpa menggunakan paradigma teori kritis, postrukturalis, dan posmodern. Alasannya adalah kajian ini didirikan di atas kerangka teoretis dan konseptual paradigma itu. Kajian budaya kontemporer (cultural studies) akhir-akhir ini begitu terkenal melalui karya-karya yang diterbitkan tahun 1960-an/1980-an oleh tokoh-tokohnya, seperti Stuart Hall, Raymond Williams, John Fisk, Richard Hoggart, E.P. Thomson dan lain-lain.

Ada kesulitan besar tentunya untuk memahami obyek kajian cultural studies dari perspektif paradigma lama yang sangat spesialis dan terlokalisir. Pada cultural studies masalah sosial, politik, filsafat, sastra, ilmu pengetahuan-teknologi, ekonomi, ras, etnis, dan perempuan (feminis) dapat saja menjadi kajian cultural studies.

Masalahnya apa yang memisahkan dan membedakan kajian ini dengan sosiologi, antropologi, politik, filsafat? Masalah perempuan dapat saja menjadi kajian feminis, tetapi juga menjadi kajian psikologi feminis, sosiologi feminis, hukum feminis, politik feminis, dan lain-lain. Demikian juga penelitian sastra tidak mungkin dapat dilakukan dengan baik tanpa memahami masalah sosial-budaya dan berbagai masalah eksistensial yang mungkin akan termuat dalam teks sastra itu. Coba saja membaca novel Neuromancer karya Wiliams Gibson yang sangat imajinatif dan sarat dengan problem ilmu pengetahuan dan tantangannya terhadap nilai-nilai kemanusiaan dengan perkembangan ilmu pengetahuan dan teknologi tinggi sekarang ini.

Mazhab Frankfurt sebelumnya telah mengembangkan berbagai model teoretis mengenai hubungan lintas disipliner antara ekonomi, negara, masyarakat, sejarah, filsafat, politik, komunikasi, teori sastra, dan kehidupan sehari-hari dengan fokusnya analisis teori sosial kontemporer (Kellner, 1995). Pemikiran tokoh Birmingham Centre for Contemporary Cultural Studies yang berkembang tahun 1960-an/1970-an sangat 
diwarnai oleh pemikiran neo-Marxis dan posmodernis. Salah satu pengaruh penting yang diterapkan cultural studies adalah pendekatan lintas disipliner dalam penelitian dan tulisan-tulisannya. Tulisan yang menunjukkan saling keterjalinan masalah sosial, ekonomi, politik, sastra, filsafat, media, sastra, iklan, masalah perempuan, etnis, ras, dapat masuk dalam kajian cultural studies. Dalam cultural studies kajian tentang satu masalah tidak-mungkin sama sekali terlepas dari masalah lain.

Cultural studies menganalisis berbagai bentuk sosial-budaya yang "hegemonik" serta berbagai kekuatan "kontra-hegemonik" sebagai perlawanan dan perjuangan memperbaiki harkat kemanusiaan. Prinsip emansipatoris pada kajian feminis dan poskolonial (cultural studies) menunjukkan pengaruh teori kritis dan posmodern. Cultural studies dapat disebut sebagai paradigma yang memayungi kajian sosial-budaya yang begitu luas sehingga terkadang dianggap ekspansionis oleh ahli bidang lain seperti sosiologi. Saling keterjalinan masalah sosial-budaya menjadi ciri penting dalam paradigma ilmiah sekarang ini. Teori kritis dan posmodern memberikan amunisi bagi teoretikus cultural studies seperti pada poskolonial dan feminis untuk mengkritik teori Barat (modern) dengan mengajukan gagasan berikut.

1. Filsafat Barat adalah aparatus dominasi, karena itu diperlukan filsafat kelompok periferal (Asia, Afrika dan Amerika Latin) sebagai fondasi filsafat pembebasan. Pemanfaatan teori berperspektif kelompok periferal ini mengembangkan teoriteori sosial-budaya baru (psikologi indigenous, terapi multikultural, feminis Afrika, dan lain-lain.

2. Universalitas filsafat Barat keliru karena ada kebutuhan, persepsi, nilai-nilai, kategori, teori, dunia lain. Ilmu pengetahuan Barat menurut pemikir feminis bersifat androsentris.

3. Filsafat Pembebasan bersifat parsial, lokal, menolak universal.

4. Batas metafisika, etika, politik modern dihancurkan. Karena itu, perlu transvaluasi nilai etika, estetika, politik Barat atau "dunia pertama" dengan perspektif dan nilai "dunia ketiga."

5. Filsafat Barat adalah filsafat pusat, metropolis dan filsafat Eropa berkulit putih (Eurosentris), di mana konsep-konsep dan masalah diidentifikasikan berdasarkan pandangannya sendiri dengan menyingkirkan pandangan lain (the Others).

6. Filsafat Barat merasionalisasi kepentingan mereka dengan mengabaikan kepentingan kelompok lain.

Jadi, filsafat dan ilmu pengetahuan sosial-budaya Barat sesungguhnya ideologis: atas dasar ini teori kritis dan posmodernis mengemukakan perlunya filsafat dan teori pembebasan karena teori Barat tidak dapat digunakan untuk membebaskan masyarakat tertindas/terpinggirkan. Karena itu, diperlukan paradigma, perspektif, dan teori yang dibangun oleh kaum tertindas. Berdasarkan argumen tersebut, terlihat nyata persamaan 
dan perbedaan teori kritis dengan teori feminis dan poskolonial dalam hal

1. sama-sama mengkritik filsafat Barat modern (teori sosial-budaya arus utama);

2. keduanya menawarkan alternatif progresif terhadap metode dan pemikiran (wacana) yang mapan;

3. keduanya sama-sama beroperasi dengan dialektika dominasi dan pembebasan.

Istilah poskolonial terkadang diidentikan dengan modern, nasional, atau kontemporer.Misalnyaistilah"sejarah sastranasional" digunakanuntukmembedakannya dengan"sejaraherakolonial", "kesusasteraan India kontemporer" untuk membedakannya dengan kesusasteraan India masa kolonial," sejarah Kanada modern" untuk mengacu pada sejarah Kanada setelah berakhirnya kolonial. Teori poskolonial termasuk teori/wacana intelektual penting sekarang ini. Tema utamanya adalah kolonialisme menimbulkan dominasi, perbudakan, pemaksaan, pergantian budaya, penyebaran agama, dan lain-lain sehingga teks poskolonial berupaya mendekonstruksi teks kolonial(is) yang selama ini telah menjadi alat kontrol yang ampuh dalam mempertahankan status quo dan hegemoni. Teks kolonial (orientalis) ternyata ampuh dalam meminggirkan dan membungkan kaum terjajah, tertindas, dan terpinggirkan.

Teori poskolonial adalah kesadaran nasionalisme dan regionalisme yang khas, yang melihat subyek dan pengalaman budaya tidak terpusat, tidak universal, pluralis/ beragam (decentring). Pengaruh kajian poskolonial di dunia akademis melahirkan kajian "sastra poskolonial" dan "feminis poskolonial". Sastra poskolonial secara implisit mengasumsikan ketidakmampuan teori sastra Eropa untuk menjelaskan kompleksitas dan keragaman yang ada pada budaya/karya sastra negeri jajahannya (kolonial). Dengan demikian, ahli sastra poskolonial mempertanyakan penggunaan genre, teori, asumsi, sifat bahasa, nilai-nilai epistemologi Barat modern dalam mengkaji sastra dan budaya negeri bekas jajahan. Teori kritis dan poskolonial menekankan dimensi pembebasan dari dominasi: ras, sistem kapitalis, budaya patriarkis, dan imperialis/kolonialis. Bagi sastra poskolonial diperlukan paradigma dan perpspektif baru yang didasarkan atas pengalaman, harapan, dan nilai-nilai budaya kaum terjajah dan terpinggirkan selama ini.

\section{DAFTAR ACUAN}

Ackerman, R. Theories of Knowledge, A Critical Introduction. New York: McGraw Hill. 1965.

Appleby, Joyce et. all. Knowledge and Postmodernism in Historical Perspective. New York: Rutledge. 1996.

Bauman, Zygmunt. Legislators and Interpreters: On Modernity, Postmoderniy and Intellectuals, Cambridge: Polity Press. 1987.

Bleicher, J. Contemporary Hermeneutics, Hermeneutics as Method, Philosophy and Critique. London: Rutledge \& Kegan Paul. 1980. 
Brooks, Thom. The Global Justice Reader. New York: Blackwell Publishing. 2008.

Castel, Gregory, ed. Postcolonial discourses An Anthology. New York: Blackwell Publisher. 2001.

Creswell, John W. Qualitative Inquiry and Research Design Choosing Among Five Traditions. London: Sage Publications. 1998.

Denzin, Norman K., \& Yvonna S.Lincoln. Handbook of Qualitative Research. London: Sage Publications. 1994.

Derrida, J. Specters of Marx: The State of the Debts. The Work of Moring, and the New International. terj. Peggy Kamuf. New York \& London: Rutledge. 1994.

. Positions. terj. Alan Bass. London: Athlon Press. 1982. . Writing and Difference. trans. Alan Bass. London: Rutledge \& Kegan Paul. 1978.

. Of Grammatology. trans. Gayatri Chakravorty Spivak. Baltimore: Johns Hopkins University Press. 1977.

Durham, Meenakshi G. dan Douglas M. Kellner. Media and Cultural studies: Key Works. New York: Blackwell Publisher. 2002.

Foucault, Michael. Discipline and Punish; The Birth of Prison. trans. Alan Seridan. London: Worcester, Billing \& Sons. 1977. . Madness and Civilization. trans. Richard Howard. New York: Random House. 1965.

Sheridan. 1972. . The Archeology of Knowledge and Discourse on Language. trans. lan . The Order of Things: An Archeology of the Human Science. New York: Random House. 1970.

Feyerabend, Paul. Against Method. London: Verso. 1975.

Gadamer. H. G. Truth and Method. London: Sheed and Ward. 1975.

Guba, Egon G., ed. The Paradigm Dialog. London: Sage Publications. 1990.

Hacking, Ian, ed. Scientific Revolution. Cambridge: Oxford University Press. 1990.

Heckman, Susan, J. Gender and Knowledge: Elements of Postmodern Feminism. Cambridge: Polity Press. 1990.

. Hermeneutics and the Sociology of Knowledge. Cambridge: Polity Press. 1986.

Honderich. Ted. ed. The Oxford Companion to Philosophy. New York: Oxford University Press. 1995.

Kellner, Douglas. Budaya Media: Cultural Studies, Identitas, dan Politik antara Modern Dan Postmodern. Yogyakarta: Jalasutra. 2010.

Kuhn, Thomas S. The Structure of Scientific Revolutions. Chicago: The Chicago University Press. 1970. . Science is a Free Society. London: New Left Books. 1978. 
. The Essential Tension: Selected Studies in Scientific Tradition and Change.

Chicago: The University of Chicago Press. 1977.

Leistyna, Pepi. ed. Cultural studies From Theory to action. New York: Blackwell. 2005.

Lubis, Akhyar Yusuf. Epistemologi Fundasional: Isu-Isu Teori Pengetahuan, Filsafat Ilmu Pengetahuan dan Metodologi. Bogor: Akademia. 2009. . Filsafat Sosial. Jakarta: Universitas Terbuka. 2010.

Mises, Richard von. Positivism: A Study in Human Understanding. New York: Dover Publications. 1951.

Rabinow, Paul. ed. The Foucult Reader. New York: Pantheon. 1984.

Ricoeur, Paul. Interpretation Theory: Discourse and Surplus of Meaning. Texas: The Texas Christian University Press. 1976.

Ritzer, George. The Postmodern Social Theory. New York: McGraw-Hill. 1996.

Rorty, Richard. Philosophy and the Mirror of Nature. New Jersey: Princeton University Press. 1980. - Objectivity, Relativism, and Truth, Vol. I. Cambridge: Cambridge University Press. 1991.

Consequences of Pragmatism. (Essay: 1972-1980), Minneapolis

University. Press. 1983.

Said, W. Edward. Peran Intelektual. Terj. dari Representations of the Intellectual. Jakarta: Yayasan Obor. 1998.

Sardar, Ziauddin dan Borin Van Loon. Mengenal Cultural Studies (For Beginners).Terj. Alfatri Aldin. Bandung: Mizan, Media Utama. 2001.

Selden, Raman. A Reader's Guide to Contemporary Literary Theory. Harvester: University of Lancester. 1985.

Sarup, Madan. An Introductory Guide to Post-Structuralism and Postmodernism. Athens: University of Georgia Press. 1989.

Sheridan, Alan. Michel Foucault: The Will to Truth. London: Travistock. 1980.

Seidman, Steven. Contested Knowledge, Social Theory in the Postmodernism Era. Cambridge: Blackwell Publisher. 1994.

Thornham, Sue. Feminist Theory and Cultural Studies: Stories of Unsetted Relation. London: Arnold. 2000.

Wallace, Walter, L. Metode Logika Ilmu Sosial. Jakarta: Yayasan Solidaritas Gama Budi Aksara. 1990. 